\title{
Thermal Lysis of Bacterial Membranes and Its Prevention by Polyamines
}

\author{
By P. H. RAY* AND T. D. BROCK \\ Department of Microbiology, Indiana University, \\ Bloomington, Indiana 4740 I, U.S.A.
}

(Accepted for publication II March I97I)

\begin{abstract}
SUMMARY
Protoplasts of Sarcina lutea and Streptococcus faecalis underwent thermal lysis when heated to $60^{\circ}$ and above. $\left[{ }^{14} \mathrm{C}\right]$ Glycine was released from the internal pool of Strep. faecalis at $50^{\circ}$. Spermine, spermidine, cadaverine and $\mathrm{Mg}^{2+}$ partially protected protoplasts against thermal lysis.
\end{abstract}

It is generally agreed that the ability of thermophiles to grow at high temperatures is due, at least in part, to their ability to synthesize heat-stable macromolecules. Brock (I967) suggested that the thermostability of the cell membrane may be an additional important factor permitting thermophiles to grow at high temperatures and this hypothesis is supported by several recent reports (Abram, I965; Golovacheva, 1967; Bodman \& Welker, 1969; Brock, 1969). Although much work has been done with spheroplasts and protoplasts of mesophilic bacteria, there have been no direct investigations of their heat stability (McQuillen, 1960).

We report thermal lysis of the protoplasts of Sarcina lutea and Streptococcus faecalis and their stabilization to heat by polyamines, agents which have been shown to stabilize bacterial protoplasts to osmotic lysis (Mager, I959; Tabor, I962; Harold, 1964).

When protoplasts of Streptococcus faecalis were held at $0^{\circ}, 37^{\circ}$ or $50^{\circ}$ for $60 \mathrm{~min}$. no lysis occurred. Incubation at $60^{\circ}$ caused slow lysis and incubation at $70^{\circ}$ caused complete lysis of the suspension in 5 to $10 \mathrm{~min}$. (Fig. I). Microscopic observations showed that the changes in extinction were due to lysis. Similar results were obtained with the protoplasts of Sarcina lutea.

Since the decrease in extinction of a protoplast suspension indicates gross lysis, a more sensitive technique was used to investigate slight membrane damage. In the presence of chloramphenicol, Streptococcus faecalis incorporates $\left[{ }^{14} \mathrm{C}\right]$ glycine into the free amino acid pool only and this compound is retained when the organisms are incubated in buffer at $0^{\circ}$ or $37^{\circ}$ (Brock \& Moo-Penn, 1962). Whole bacteria containing $\left[{ }^{14} \mathrm{C}\right]$ glycine in their pools can thus be used to study the effect of temperature on the stability of the membrane. Radioactive glycine was released from the internal pool at a significant rate at $50^{\circ}$, and at temperatures of $60^{\circ}$ or over, loss of the radioactive material was essentially complete in $3 \mathrm{~min}$. (Fig. 2). When suspensions of $S$. faecalis labelled in DNA by incubation by $\left[{ }^{14} \mathrm{C}\right]$ thymidine with excess uracil were subjected to the same temperatures for up to $30 \mathrm{~min}$. essentially no radioactivity was released.

Addition of polyamines and metal ions to protoplasts of Sarcina lutea and Streptococcus faecalis gave some protection against heating for $60 \mathrm{~min}$. at $60^{\circ}$. Spermine $(5 \mathrm{mM})$ and

* Present address: Department of Biochemistry, University of Kentucky, Lexington, Kentucky 40502, U.S.A. 
spermidine (20 mM) gave essentially complete stabilization, while magnesium, cadaverine, and streptomycin (all $20 \mathrm{mM}$ ) were partly effective. Other cations $\left(\mathrm{Ca}^{2+}\right.$, lysine, ornithine and putrescine) were only weakly active or ineffective. The order of effectiveness of these compounds is similar to that on osmotic fragility (Harold, I964) and binding to nucleic acid (Brock \& Wooley, 1963), the effective compounds being those which have the highest cation charge density. Lower concentrations of polyamines gave partial protection against thermal lysis, and in the presence of $50 \mathrm{mM}-\mathrm{NaCl}$ or phosphate the polyamines were no longer effective in preventing thermal lysis.

These results show that temperature causes destruction of the protoplast membrane of mesophilic bacteria and that this destruction can be prevented by polyamines.

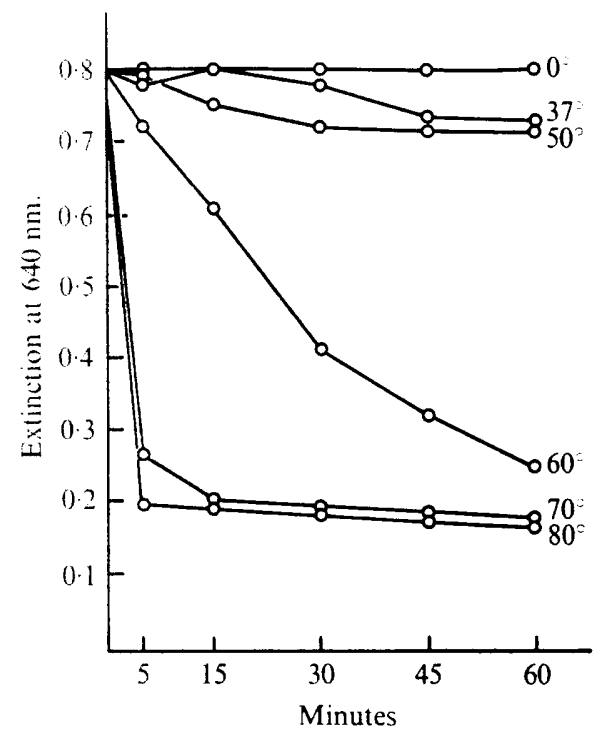

Fig. I

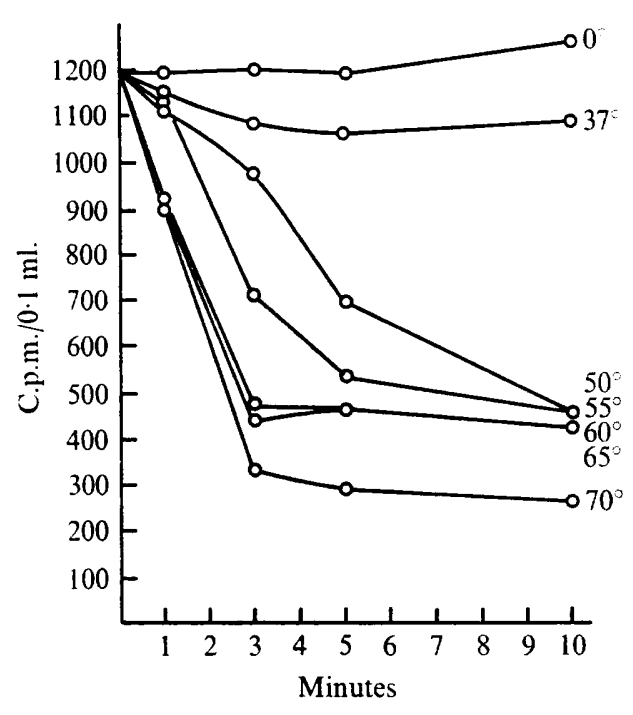

Fig. 2

Fig. I. Effect of temperature on protoplasts of Streptococcus faecalis (ATCC 9790) in isotonic medium. The protoplasts, made as described by Harold (I964), were stabilized in I M-sucrose. The suspensions were incubated at various temperatures for the time periods given, and after cooling the extinction was measured at $640 \mathrm{~nm}$.

Fig. 2. Effect of various temperatures on the release of $\left[{ }^{14} \mathrm{C}\right]$ glycine from the pool of suspensions of Streptococcus faecalis. $\left[{ }^{14} \mathrm{C}\right]$ Glycine was allowed to accumulate in the free amino acid pool of S. faecalis (Brock \& Moo-Penn, 1962). After washing in $\mathrm{PO}_{4}-\mathrm{NaCl}$ buffer the suspensions were incubated at the various temperatures described and filtered through membrane filters which were counted in a Nuclear Chicago gas-flow counter.

This investigation was supported by the National Institutes of Health training grant 5TI GM 503 and National Science Foundation grant GB-7815.

\section{REFERENCES}

ABRAN, D. (1965). Electron microscope observations on intact cells, protoplasts, and the cytoplasmic membrane of Bacillus stearothermophilus. Journal of Bacteriology 89, 855-873.

BODMA.N. H. \& WELKER, N. E. (I969). Isolation of spheroplast membranes and stability of spheroplasts of Bacillus stearothermophilus. Journal of Bacteriology 97, 924-935.

Brock. T. D. (1967). Life at high temperatures. Science, New York 158, Ior 2-Ior9.

Brock. T. D. (1969). Microbial growth under extreme conditions. Symposia of the Society for General Microbiology 19, I 5-4 I. 
Brock, T. D. \& Moo-PenN, G. (1962). An amino acid transport system in Streptococcus faecium. Archives of Biochemistry and Biophysics 98, 183-196.

Brock, T. D. \& Wooley, S. O. (1963). Streptomycin as an antiviral Agent: mode of action. Science, New York 14I, 1065-1067.

GolovacheVA, R. S. (1967). Spontaneous generation of spherical forms in obligate thermophilic bacilli. Microbiologya (U.S.S.R.) 36, 560-565.

HAROLD, F. M. (1964). Stabilization of Streptococcus faecalis protoplasts by spermine. Journal of Bacteriology 88, $1416-1420$.

MAGER, J. (1959). The stabilizing effect of spermine and related polyamines on bacterial protoplasts. Biochimica et biophysica acta 36, 529-53r.

MCQuillen, K. (1960). Bacterial protoplasts. In The Bacteria, vol. I, pp. 249-359. Edited by I. C. Gunsalus \& R. Y. Stanier. New York: Academic Press.

TABOR, C. W. (1962). Stabilization of protoplasts and spheroplasts by spermine. Journal of Bacteriology 83 , IIOI-IIII. 